\title{
Exocrine pancreatic enzyme and calcium secretion in health and pancreatitis*
}

\author{
J E CLAIN, $\uparrow$ G O BARBEZAT, AND I N MARKS $\ddagger$ \\ From the Gastrointestinal Clinic, Groote Schuur Hospital, and the Department of Medicine, \\ University of Cape Town Medical School, Cape Town, South Africa
}

SUMMARY Calcium, enzyme, and total protein secretion were measured in secretin stimulated pancreatic juice in health, 'early' chronic pancreatitis, and in chronic calcific pancreatitis. Increased concentrations of trypsin, total protein, and calcium, and increased outputs of calcium and protein were shown to be present in the 'early' stages of the disease, indicating that an environment conducive to the formation of protein plugs and possibly later calcification already exists.

The concentration of pancreatic juice enzyme ${ }^{1}$ and calcium $^{2-6}$ is increased in established chronic pancreatitis. Supersaturation and precipitation of enzymes in the pancreatic ducts give rise to the protein plugs found in calcific pancreatitis, and are regarded as important in the pathogenesis of the disease. ${ }^{7}$ The cause of the raised calcium levels in pancreatic juice in this disease is uncertain.

The purpose of this study was to determine whether the raised calcium and enzyme levels in chronic pancreatitis are found only in the calcific forms of the disease, or whether they may occur in earlier forms of the disease as well. To test this we measured calcium, protein, and trypsin in hormonally stimulated duodenal juice of control subjects, subjects after complete resolution of a documented attack of clinically acute alcohol-induced pancreatitis (post-acute pancreatitis (PAP), and in subjects with alcohol-induced chronic calcific pancreatitis (CCP).

\section{Methods}

\section{SUBJECTS}

Thirty-two individuals of all races were studied. All gave informed consent for the same investigation. The individuals studied were of three groups: (1) healthy volunteers who acted as controls (12 subjects,

-This report was supported by a grant from the Medical Research Council of South Africa.

tAddress for correspondence: Dr J E Clain, Division of Gastroenterology, Mayo Clinic, Rochester 55901, Minnesota, USA.

¥Address for reprint requests: Dr I N Marks, Gastrointestinal Clinic, Groote Schuur Hospital, Observatory 7925, Cape Town, South Africa.

Received for publication 25 November 1980 six studied with secretin background, and six with a background secretin and cholecystokinin (CCK)); (2) patients at least six weeks after an episode of clinically acute alcohol-induced pancreatitis confirmed by a serum amylase of more than 600 Pimstone units per $\mathrm{ml}^{8}$ during an attack (11 patients, six with secretin background, and six with a background of secretin and CCK); (3) patients with chronic calcific pancreatitis (CCP) evident radiologically (nine patients, four with secretin background, and six with a background of secretin and CCK).

\section{EXPERIMENTAL DESIGN}

After a 10 hour overnight fast a radio-opaque nasogastric tube (Rusch, size 14 or 16) was positioned with its distal tip at the junction of the second and third parts of the duodenum. A second tube was placed in the dependent portion of the stomach. The position of both tubes was frequently checked fluoroscopically throughout the test. Constant siphonage at a pressure of -50 to $-80 \mathrm{~cm}$ of water and regular manual syringing of the tubes ensured constant patency. After a basal period a constant infusion of secretin (Boots, $1 \mathrm{unit} / \mathrm{kg} / \mathrm{h}$ ) or a combination of secretin (1 unit $/ \mathrm{kg} / \mathrm{h})$ and CCK (Boots, 1 unit $/ \mathrm{kg} / \mathrm{h}$ ) was started, using a constant infusion pump (Braun, Melsungen) and continued for 60 minutes. Duodenal samples were collected under ice at 10 minute intervals, and the volume recorded.

\section{SAMPLE ANALYSIS}

Protein concentration was estimated by comparing absorbance at $280 \mathrm{~nm}$ with standards of bovine serum albumin. Trypsin was determined spectrophotometrically using benzyl-L-arginine ethyl ester 
as a substrate. ${ }^{9}$ Calcium concentration was measured using an atomic absorption spectrophotometer (Varian-Techtron, Melbourne, Australia). Bicarbonate concentrations were determined by adding $1 \mathrm{ml} 0 \cdot 1 \mathrm{M} \mathrm{HCl}$ to $0.5 \mathrm{ml}$ of sample, boiling, and backtitrating to $\mathrm{pH} 7$ with $0.2 \mathrm{M} \mathrm{NaOH}$ using an automatic titrator (Radiometer, Copenhagen, Denmark). Gastric juice was collected separately and discarded.

\section{STATISTICAL ANALYSIS}

Statistical analysis was carried out using Student's $t$ test for unpaired values, and correlation coefficient by the least squares method.

\section{Results}

SECRETIN STIMULATED CALCIUM, PROTEIN, AND TRYPSIN SECRETION

Calcium secretion

Calcium concentration and output in secretinstimulated subjects is shown in Fig. 1. Calcium con-

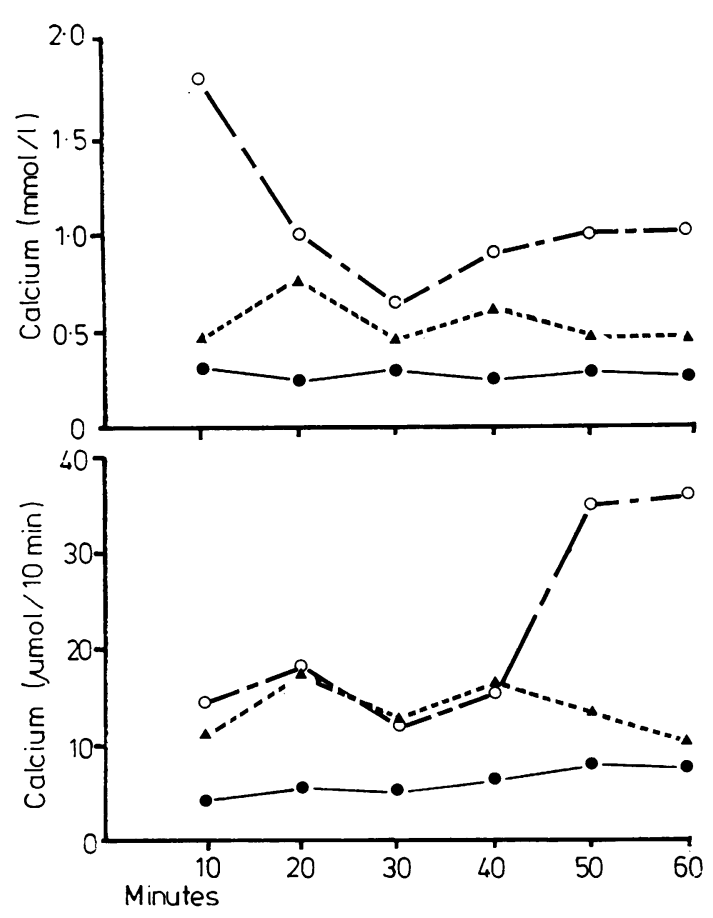

Fig. 1 Secretin stimulated calcium concentration and output. In controls (O) the mean 60 minute calcium concentration was $0.26 \pm 0.06 \mathrm{mmol} / \mathrm{l}$ (mean $\pm S E M)$, and the peak 10 minute calcium output $10.61 \pm 0.32 \mu \mathrm{mol}$. In the PAP subjects ( $\Delta$ ) mean 60 minute calcium concentration was $62 \pm 0.06 \mathrm{mmol} / \mathrm{l}$, and peak 10 minute calcium output $20.95 \pm 3.33 \mu \mathrm{mol}$. PAP values were significantly greater than control values, $\mathrm{P}<0.01$ and $\mathbf{P}<0.05$ for calcium concentration and output respectively. $O: C C P$.
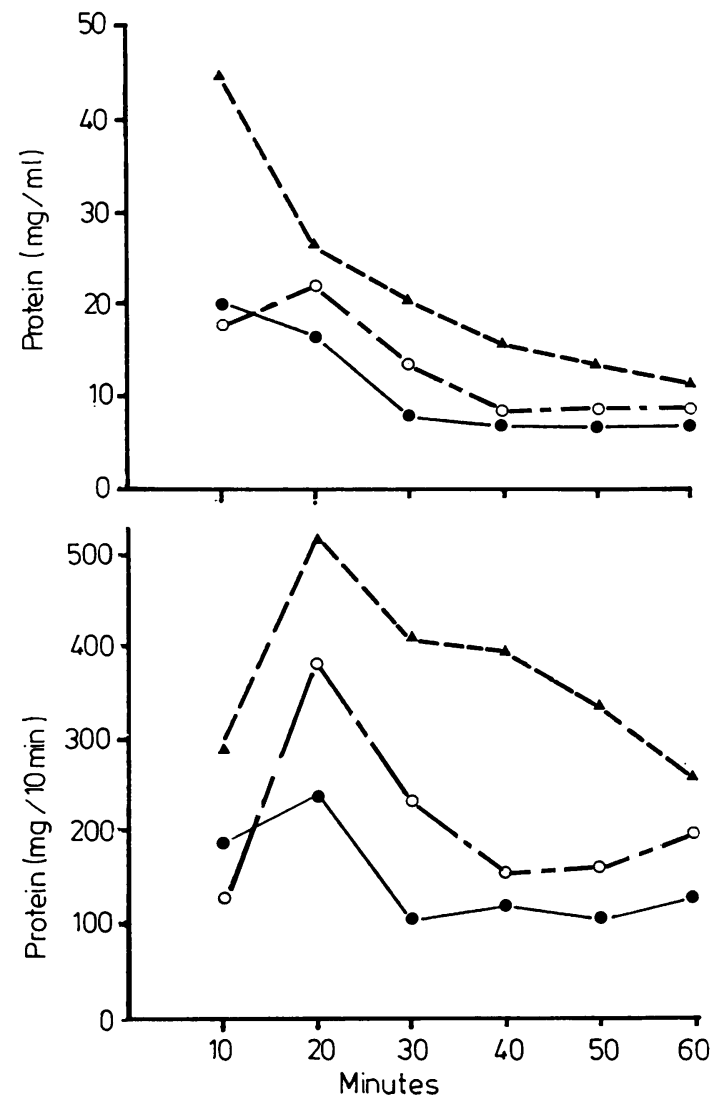

Fig 2. Secretin stimulated protein concentration and output. In control subjects (O) mean 60 minute protein concentration was $9.62 \pm 1.84 \mathrm{mg} / \mathrm{ml}($ mean \pm SEM), and 60 minute protein output $873 \pm 131 \mathrm{mg}$. In PAP subjects

( $\Delta$ ) mean protein concentration was $20 \cdot 15 \pm 3.96 \mathrm{mg} / \mathrm{ml}$, and 60 minute protein output $2804 \pm 549 \mathrm{mg}$. PAP values were significantly greater than control values, $\mathrm{P}<0.05$ and $\mathbf{P}<0.01$ for concentration and output respectively.

$O: C C P$.

centration and output in control subjects was consistently lower than in PAP subjects, both for the mean 60 minute calcium concentration $(P<0.01)$ and peak 10 minute calcium output $(P<0.05)$. There was no significant difference in calcium concentration or output between PAP and CCP subjects.

\section{Protein secretion}

Protein concentration and output after secretin is depicted in Fig. 2. PAP values were consistently higher than control values for mean 60 minute protein concentration $(\mathrm{P}<0.05)$ and 60 minute protein output $(\mathrm{P}<0.01)$, while there was no statistical difference between control values and those in CCP subjects. 


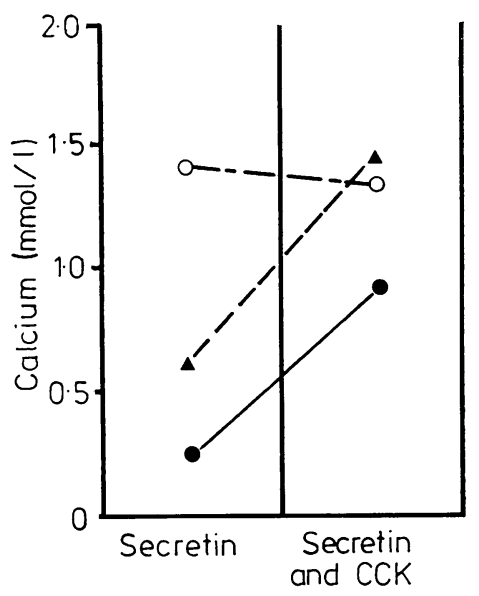

Trypsin secretion

Trypsin secretion paralleled that of protein secretion. The mean 60 minute trypsin concentration in controls was $1912 \pm 261$ (mean \pm SEM) BAEE units $/ \mathrm{ml}$, and the mean trypsin concentration in PAP subjects was significantly higher, $2913 \pm 263$ BAEE units $/ \mathrm{ml}, \mathbf{P}<0.025$. The trypsin output in controls was $223 \pm 59$ BAEE units/10 minutes $\times 10^{3}$, and that in PAP subjects $376 \pm 87$ BAEE units/10 minutes $\times 10^{3}$, which just failed to reach statistical significance.

Table 1 Mean bicarbonate concentration and peak bicarbonate output in controls, postacute pancreatitis, and in chronic calcific pancreatitis.

\begin{tabular}{llll}
\hline & $\begin{array}{l}\text { Controls } \\
n=12\end{array}$ & $\begin{array}{l}\text { Post-acute } \\
\text { pancreatitis } \\
n=11\end{array}$ & $\begin{array}{l}\text { Chronic } \\
\text { calcific } \\
\text { pancreatitis } \\
n=9\end{array}$ \\
\hline Bicarbonate & $110 \cdot 7$ & $89 \cdot 1$ & $69 \cdot 8$ \\
(mmol/1) & \pm 3.48 & $\pm 7 \cdot 1 *$ & $\pm 5 \cdot 6 \dagger$ \\
Bicarbonate & $4 \cdot 00$ & $2 \cdot 93$ & 1.56 \\
(mmol/10 min) & \pm 0.46 & \pm 0.52 & $\pm 0.23 \dagger$ \\
\hline
\end{tabular}

Data are mean \pm SEM from secretin and combined secretin and CCK stimulated subjects. ${ }^{*} \mathrm{P}<0.05,+\mathrm{P}<0.01$ compared with control values.
In CCP subjects, trypsin concentration and output was $1505 \pm 352$ BAEE units $/ \mathrm{ml}$, and $155 \pm 65$ BAEE units $/ 10$ minutes respectively, which was not significantly different from control values.

\section{EFFECT OF COMBINED SECRETIN AND CCK ON PROTEIN AND CALCIUM SECRETION \\ Calcium secretion}

Combined infusion of secretin and CCK increased both calcium concentration and output in control subjects $(\mathrm{P}<0.05, \quad \mathrm{P}<0.01)$ and $\mathrm{PAP}$ subjects $(\mathrm{P}<0.02, \quad \mathrm{P}<0.01)$ (Fig. 3). In contrast, calcium secretion in CCP subjects, which was high in response to secretin, showed no increase in either concentration or output after CCK.

\section{Protein secretion}

The 60 minute protein output after secretin and CCK in control subjects was $4198 \pm 852 \mathrm{mg}$ (mean \pm SEM). In PAP subjects the mean protein output was comparable with $4442 \pm 818 \mathrm{mg}$, while in CCP subjects protein output was only $1985 \pm 620 \mathrm{mg}$.

Table 2 Calcium concentrations and outputs after secretin, and secretin and cholecystokinin in controls, post-acute pancreatitis, and in chronic calcific pancreatitis

\begin{tabular}{|c|c|c|c|c|c|c|}
\hline & \multicolumn{2}{|l|}{ Controls } & \multicolumn{2}{|c|}{ Post-acute pancreatitis } & \multicolumn{2}{|c|}{ Chronic calcific pancreatitis } \\
\hline & $(\mathrm{mmol} / 1)$ & (umol/60 min) & $(\mathrm{mmol} / 1)$ & ( $\mu \mathrm{mol} / 60 \mathrm{~min})$ & $(\mathrm{mmol} / 1)$ & ( $\mu \mathrm{mol} / 60 \mathrm{~min})$ \\
\hline & $\begin{array}{r}0.26 \\
+0.06\end{array}$ & $32 \cdot 7$ & 0.62 & $62 \cdot 5$ & $1 \cdot 38$ & $127 \cdot 8$ \\
\hline $\begin{array}{l}\text { Secretin and CCK } \\
\mathbf{P}\end{array}$ & $\begin{array}{r} \pm 0.06 \\
0.93 \\
\pm 0.26 \\
<0.05\end{array}$ & $\begin{array}{r} \pm 8.41 \\
205.0 \\
\pm 50.0 \\
<0.01\end{array}$ & $\begin{array}{r} \pm 0.06 \\
1.44 \\
\pm 0.29 \\
<0.02\end{array}$ & $\begin{array}{l} \pm 11.10 \\
174.0 \\
\pm 35.69 \\
<0.01\end{array}$ & $\begin{array}{r} \pm 0.65 \\
1.36 \\
\pm 0.34 \\
\mathrm{NS}\end{array}$ & $\begin{array}{l} \pm 59.5 \\
142.0 \\
\pm 52.77 \\
\text { NS }\end{array}$ \\
\hline
\end{tabular}

Data represented are the mean \pm SEM. The addition of CCK produces a significant rise in both concentration and output of calcium in controls and post-acute pancreatitis, but not in chronic calcific pancreatitis. 
CORRELATION BETWEEN CALCIUM AND

PROTEIN SECRETION

There was no correlation in secretin and CCK stimulated calcium and protein secretory values in control subjects or in subjects with pancreatic disease (data not shown).

\section{Bicarbonate secretion}

Peak bicarbonate secretory values are shown in Table 1, and data have been pooled for secretin stimulated, and secretin and CCK stimulated subjects. In PAP subjects there was significantly decreased bicarbonate concentration but not output, while in CCP there was reduced bicarbonate concentration and output in relation to control values.

\section{Discussion}

The vast majority of patients with clinically acute alcohol-induced pancreatitis have established pathological ${ }^{10}$ and functional ${ }^{11}$ changes at the time of the first attack, and were considered to be a suitable group of patients for studying the changes in the 'early' form of the chronic disease. Bicarbonate values in Table 1 suggest that function in these subjects is impaired, while protein secretion after secretin and CCK (Table 2) indicate that such impairment is minimal.

The results of the study indicate that secretin stimulated enzyme and calcium secretion is increased in 'early' disease. Both concentration and output of calcium and protein are increased, showing that this is not simply decrease in volume flow, but an absolute increase in production. This suggests that an environment conducive to the formation of protein plugs, and possibly later calcification, already exists at an early stage of pancreatitis.

Various factors may be involved in the raised calcium and protein levels in pancreatitis. Damage to the pancreatic duct system in pancreatitis may allow increased 'leak' of calcium into pancreatic juice, and, as calcium in serum is higher than that normally present in pancreatic juice, this could account for the rise in juice calcium. However, individual 10 minute calcium outputs, particularly in calcific pancreatitis, occasionally greatly exceeded serum values, and this cannot, therefore, be the complete explanation. Secondly, it is interesting to speculate whether the high protein and calcium levels in pancreatitis may not perhaps be related to the allegedly high levels of CCK in patients with chronic pancreatitis. ${ }^{12}$
The present study confirms the observations of previous workers regarding the increased pancreatic juice calcium levels after CCK stimulation, ${ }^{213-15}$ but has failed to show the positive correlation between calcium and enzyme secretion reported by Goebell and his co-workers in the experimental animal. ${ }^{14}$ Biliary contamination of pancreatic juice may have obscured possible correlation, but, alternatively, our results could indicate that calcium enters the pancreatic juice by more than one route.

\section{References}

${ }^{1}$ Sarles H. Alcoholism and pancreatitis. Scand J Gastroenterol 1971; 6: 193-8.

${ }^{2}$ Gullo L, Sarles H, de Barros Mott C, Tiscornia O, Pauli AM, Pastor J. Pancreatic secretion of calcium in healthy subjects and various diseases of the pancreas. Rendic Gastroenterol 1974; 6: 35-44.

${ }^{3}$ Goebell H, Bode C, Horn HD. Einflub von Sékretin und Pankreozymin auf die Calciumsekretion in menschlichen duodenalsaft bei normaler und gestörter Pankreas funktion. Klin Wschr 1970; 48: 1330-9.

${ }^{4}$ Nimmo J, Finlayson HDC, Smith AF, Shearman EJC. The production of calcium and magnesium during tests of pancreatic function in health and disease. Gut 1970; 11: 163-6.

${ }^{5}$ Strum WB, Spiro HM, Hersh T. Studies on the relationship of pancreatic juice calcium to calcific pancreatitis. Gastroenterology 1970; 58: 998.

${ }^{6} \mathrm{Hansky} \mathrm{J}$. Calcium content of duodenal juice. Am J Dig Dis 1967; 12: 725-33.

${ }^{7}$ Sarles H. Chronic calcifying pancreatitis-chronic alcoholic pancreatitis. Gastroenterology 1974; 66: 604-16.

${ }^{8}$ Pimstone NR. A study of the starch iodide complex: a modified colourimetric micro determination of amylase in biological fluids. Clin Chem 1964; 10: 891-906.

${ }^{8}$ Schwert GW, Takenaka Y. A spectrophotometric determination of trypsin and chymotrypsin. Biochim Biophys Acta 1955; 16: 570-5.

${ }^{10}$ Strum WB, Spiro HM. Chronic pancreatitis. Ann Interm Med 1971; 74: 264-77.

"Marks IN, Bank S, Louw JH. Chronic pancreatitis in the Western Cape. Digestion 1973; 9: 447-53.

${ }^{12}$ Harvey RF, Dowsett L, Hartog M, Read AE. A radioimmunoassay for cholecystokinin pancreozymin. Lancet 1973; 2: 826-8.

${ }^{13}$ Zimmerman MJ, Dreiling DA, Rosenberg IR, Janowitz HD. Secretion of calcium of the canine pancreas. Gastroenterology 1967; 52: 865-70.

${ }^{14}$ Goebell H, Steffen C, Bode C. Stimulatory effect of pancreozymincholecystokinin on calcium secretion in pancreatic juice of dogs. Gut 1972; 13: 447-82.

${ }^{15}$ Scratcherd T, Case RM. The secretion of electrolytes by the pancreas. Am J Clin Nutr 1973; 26: 326-39. 